Omalium rufipes.

Protinus atomarius.

Micropeplus tesserula.
Pycnoglypta lurida.

11 convexa.

And about 6 species not yet identified.

\title{
A NEW TENTHREDINID.
}

BY L. PROVANCHER, CAP ROUGE, QUEBEC.

\section{Genus Synairema, Hartig.}

This genus was detached from Tenthredo by Hartig in 1837 , for an insect described in 1793 by Panzer, under the name of Tenthredo rubi, found in Germany, Sweden, France, Tyrol, \&c. In I 849, Bremi described a new species found in Helvetia, which he named $S$. alpina. It has not yet been recorded as met with in America.

Synairema differs only from Tenthredo by its lanceolate cell, which is largely contracted in the middle, while in the last it is separated by a straight nervule.

\section{Synairema Americana, nov. sp.}

ㅇ.-Length .46 inch. Black; face below the antennæ, inner orbital lines reaching the occiput and thence curving inwards, mandibles, clypeus, palpi, genæ, scape underside, a spot on each side of the median lobe of mesothorax, a spot on tegula, scutel, a point before and another one behind, apex of basal plates, pleura and pectus in parts, white. Antennæ long, slender, black with a white spot on the scape underneath. Wings hyaline, nervures and stigma brown black. Legs white, including coxæ and trochanters, the two anterior pairs with a black line exteriorly on their femora, tibiæ and tarsi; the posterior pair black, with coxæ, except a black spot outside, trochanters and basal third of femora, white; the spines of their tibize, except the tips, and a ring at the base of the first joint of the tarsus, also white. Abdomen elongated, black, shining, venter more or less whitish on the sides. Valves of the terebra black, shortly exserted.

Captured one female at Cap Rouge, 